Original scientific paper

UDK:327:338.24(48)

DOI: $10.5937 /$ jrs14-19697

Received: 28 November 2018 / Accepted: 12 August 2019

\title{
Governance Entrepreneurs as Spoilers in Nordic Defence Cooperation*
}

\author{
MAREN GARBERG BREDESEN** \\ Norwegian Institute of International Affairs (NUPI), Norway \\ KARSTEN FRIIS ${ }^{* * *}$ \\ Norwegian Institute of International Affairs (NUPI), Norway
}

\begin{abstract}
The deteriorated security situation in Europe has contributed to a renewed focus on Nordic defence cooperation. Recent political statements indicate an increased interest among the Nordic states to strengthen regional security cooperation in times of peace, crisis and conflict. Nonetheless, the main obstacles preventing close integration remain in place, in particular the different strategic orientations when it comes to NATO and EU membership among the Nordics. While this is well known among scholars, less emphasis has been on the lowerlevel challenges Nordic defence cooperation initiatives has met. Bureaucratic mismatches and diverging industrial interests can have an important negative impact on politically endorsed projects. Governance entrepreneurs can not only undermine a specific project, but may also contribute negatively to the larger political climate between states. This article will illustrate the argument with several cases of botched Swedish-Norwegian cooperation, with particular emphasis on the Archer artillery project. This was a politically prestigious joint procurement project which failed, with significant souring of political relations as a result.
\end{abstract}

Keywords: NORDEFCO; Governance entrepreneurs, Archer artillery, Norway, Sweden.

* This article is a result of a research project funded by the Norwegian Ministry of Defence. Thanks to Pernille Rieker, Ole Jacob Sending, the anonymous peer reviewers and the editors for valuable comments and suggestions.

**: maren.bredesen@gmail.com

**:*kf@nupi.no 


\section{Introduction}

The Nordic region's strategic and geopolitical significance has shifted after the Russian annexation of Crimea and incursion into Ukraine. The growing Russian military and political assertiveness in the broader Nordic-Baltic region has made the region a strategic hot-bed, and several key allies of the Nordic countries, like the UK and USA, now increasingly see the Nordics and the Baltics as comprising one operational theatre. Also, among the Nordic countries, feelings of interdependence have gained momentum. In 2015, the Nordic defence ministers issued a joint opinion on the need for enhanced defence cooperation in the face of an unpredictable Russia; ${ }^{1}$ and NATO Secretary General Jens Stoltenberg stressed the importance of Nordic defence cooperation as a way to strengthen security in the Nordic-Baltic region. ${ }^{2}$ In May 2016, US President Obama invited the Nordic prime ministers jointly to Washington for a US-Nordic summit and encouraged them to 'stick together', further advancing the Nordics as a common force. ${ }^{3}$ In 2018 the Nordic defence ministers declared that they 'will improve our defence capability and cooperation in peace, crisis and conflict.'

This increased Nordic security interdependence has been described as a 'new norm' which gives rise to fresh questions about the Nordic countries and regional security and defence cooperation. Since the creation of Nordic Defence Cooperation (NORDEFCO) in 2009, cooperation in the security and defence domain has fluctuated between momentums and disincentives and has often proven surprisingly complex and challenging. The Nordic region constitutes a regional cluster of conflicts of interest and institutional complexity that creates its own systems of both cooperation and competition. The many fault-lines have made regional defence cooperation challenging, conflict-ridden and subject to setbacks in recent years.

Perhaps the most prevalent impediment to Nordic defence cooperation has been the disparity in institutional configurations and affiliations, leading to diverging - and sometimes incompatible -lines in defence and foreign policy. Finland and Sweden are formally non-aligned and remain outside NATO, but contribute fully to the EU Common Security and Defence Policy (CSDP); Iceland and Norway remain outside the EU, but are members of NATO. Denmark is a member of both the EU and NATO, but has opted out of CSDP defence matters.

A different explanation for the challenges experienced lies with bureaucratic mismatches between the Nordic defence administrations, which in turn have led to poor communication and differences in perceptions between key stakeholders - with the potential to set negative precedents for Nordic cooperation as regards defence materiel. Furthermore,

1 Søreide et al. 2015.

2 NATO News 2015.

3 Harris 2016.

$4 \quad$ NORDEFCO 2018. 
the Nordic states' respective defence industries have served as both a generator for but also impediment to Nordic defence cooperation - with impediments often being the consequence of overlapping industrial competences that are subject to differing ownership structures and industrial strategies. However, this industrial aspect of Nordic security cooperation has received little analytical scrutiny.

In order to understand the character of Nordic security and defence cooperation today and its future prospects - it is essential to be aware of the institutionalized bureaucratic practices and industrial interests at play at the implementing level of Nordic defence planning and cooperation. This grassroots level of analysis shows that bureaucratic practices and industrial concerns are deeply involved in setting the premises for regional defence cooperation - even operating with a degree of autonomy that allows them to propel political initiatives into uncharted areas.

By showing how the practices of local actors (specifically: defence bureaucracies and industries) influence the shaping of policies for regional cooperation, this article aims to contribute to explaining how regional security conditions and dynamics can prove difficult despite good intensions. The relationship between Norway and Sweden is taken as the point of departure because these two countries have been central in the development of Nordic security and defence cooperation as it has advanced from 2009. More specifically, the article will use the case of the failed joint artillery procurement, the Archer system, to illustrate the crucial role both bureaucracies and industry can have in implementing, or undermining, defence cooperation in practice.

In the following the article will first briefly discuss a set of theoretical approaches to studying regional security policies, before introducing Nordic defence cooperation. In the following sections the Norwegian and Swedish defence bureaucracies, as well as the Nordic defence industry will be discussed. After that, the case of the failed Archer project will be assessed in more detail, demonstrating the influence of the local actors, which we will label governance entrepreneurs. The ensuing analysis aims to offer a more 'agency-sensitive' understanding of recent changes and developments in the sphere of Nordic security. The article will conclude with a reflection of the lessons learned and the future of Nordic defence cooperation. 


\section{Analysing Nordic Security}

In an article back in 1994, Iver B. Neumann used the terms outside-in and inside-out to describe how a region is generated. ${ }^{5}$ The former, he argued, is typically focused on big power geopolitics, while that latter is cultural integrations leading to what Karl W. Deutsch called a security community. Applying this in the Nordic context, he held that the inside-out factors had been as important as outside-in factors. The Nordic relative peace and stability was primarily a result of clever policies of the Nordic states, not a deliberate superpower restraint. ${ }^{6}$

Building on this model, we could say that in the outside-in perspective, geopolitics and global levers - external push factors - are considered the dominant factors explaining the evolution of Nordic security policies. The inside-out perspective would rather put emphasis on internal patterns of enmity and amity - generated internally by history, politics and material conditions.

From an outside-in perspective, one can argue that since 2014, European security has become more forcefully structured between Russia on one side, and NATO and the transatlantic link on the other. ${ }^{7}$ The Nordics are located at the intersection of these two poles, as evidenced by the patterns of military exercises in the Nordic region, incidents of Russian overflights over Swedish territory, and the recent deployment of several NATO battalions in the Baltic states and Poland. The argument is thus that the Nordic region predominantly is defined negatively, by its surrounding geopolitical environment. For example, Breitenbauch sees this dynamic as the inescapable geopolitical situation of the Nordics; a spatial situation that they will continuously be 'thrown' into. ${ }^{8}$ Intensified Nordic security cooperation as a response to increased Russian assertiveness in the Baltic Sea since 2014 is one example where exogenous actions have created conditions for renewed political integration in the Nordic space. Similarly, the end of the Cold War made it possible for new political dynamics to emerge. ${ }^{9}$ Within this interpretation, political region-making is essentially mediated by exogenous security relationships - by the structure and behaviour of global superpowers, or the outside-in.

$5 \quad$ Neumann 1994.

6 Neumann's argument is that rather than weighing the inside-out and outside-in factors against each other, one should ask who it is that draws the line between the inside and the outside of the region, thus building something as a region (58). The political construction of the Nordic region is not the focus in this article, but we will nonetheless borrow his terminology to illustrate the policy flows in Nordic security.

7 Breitenbauch 2015, 120.

8 Ibid.

9 Breitenbauch 2015, 116; Forsberg 2013, 1175. 
However, although the structural conditions for Nordic cooperation might be given, this approach face limitations in explaining regional change. According to this logic, domestic changes towards integration must happen in connection with externally given shifts. This is problematic, as it pays little attention to alternative sources of change inside regions, and the role of local agents in constituting and shaping the Nordic security region. This in turn relates back to the question of regional creators, agency and change. Here, the inside-out refers to the internal processes in which the concerns generated within a region produces a regional policy: regional actors define a problem and interact to produce a collective response over the issue. Enhancing Nordic cooperation because of Russia's actions since 2014is a case in point. As the five Nordic defence ministers put it in 2015: "The Nordic countries meet the present situation through solidarity and enhanced cooperation". ${ }^{10}$ However, while this statement sets the framework for future regional interaction, to what extent does it actually reflect the dynamics between relevant actors on ground?

We will argue that to grasp the dynamics of regional cooperation we should begin with the premise that in everything that politicians do, there is always a practical substratum of actors operating in parallel that does not necessarily derive from conscious deliberation, thoughtful reflection, or policies resulting from external pressure. ${ }^{11}$ Global powers may penetrate the region and politicians may articulate policy responses, but this does not alone determine the regional dynamics. There may be both resistance and initiatives emerging from the bottom-up, contributing to the continuous shaping and formulation of regional security cooperation.

Security policies must be implemented by someone - bureaucrats, institutions, corporates or other agents -who themselves usually have some kind of policy or interest agenda. Locating these actors and evaluating their impact on regional security dynamics is essential for understanding security regions. Indeed, anticipating changes in political or regional orders requires accounting for the creation and re-creation of practices that are partly the result of deliberate policies adopted by existing authorities, and that partly arise when individuals, groups and organizations interact.

In order to understand dynamics of the Nordic security region it is therefore essential to address the domestic or local level - the 'floor', where practices are tested and applied, negotiated and disputed by local agents like industries and bureaucrats. An analysis of Nordic security cooperation calls for a perspective that can account for local actors and their role in defining the regional environment from the bottom and upwards. Somewhat in line with functionalist arguments ${ }^{12}$ this article recognizes local actors and their capacity to take control and push forward political and regional cooperation processes.

10 Søreide et al. 2015.

11 See Pouliot 2010, 12.

12 See Haas 1964; also Schmitter 2004, 2005. 
Inspired by Liliana B. Andonova's acclaimed work, we call these local actors governance entrepreneurs. Andonova's primary focus is on international organizations (IOs) and their role in shaping international politics through various forms of hybrid governance. Nevertheless, there are certain parallels with state bureaucracies and their role in implementing international (as opposed to national) policies. They can arguably be more entrepreneurial in such settings than in national processes, as their procedures to implement a given international project may be less embedded in national practice, regulations and legislation. It can require innovative new approaches, but also bending and stretching of rooted national procedures and practices. For instance, if two cooperating countries have different planning or procurement procedures, they will need to find a common ground to be able to implement joint processes.

Furthermore, the logical flipside of the idea of a governance entrepreneur must be that these entrepreneurs also possess the potential to undermine or circumvent the policies implemented by states on the political level. Hence, as outside-in and inside-out forces on the political level may push for more cooperation, the governance entrepreneurs may rather resist or obstruct these initiatives. In effect they could function as spoilers of higher-level cooperation initiatives, for professional or other reasons that can be perfectly rational and legitimate from their perspective. Furthermore, such obstructions may not only undermine the initiative in question, but can also impact negatively on the broader regional political climate, thus undermining the political willingness to cooperate on other issues as well.

\section{Nordic Defence Cooperation: Ambitions and Realities}

One way of explaining what or who creates, practices and maintains regional cooperation in the field of Nordic security is to focus on regional cooperation forums. The Nordic Defence Cooperation (NORDEFCO) is a comprehensive institutional framework that resulted from intra-Nordic discussions about practical pressures for more extensive defence cooperation in view of global security requirements like multinational missions. ${ }^{13}$ Substantial attention has also been paid to the importance of individuals as a driving force, more specifically Norwegian Chief of Defence (CHOD) Sverre Diesen, Swedish CHOD Håkan Syrén and Finnish CHOD Pauli Juhani Kaskeala, who were central to the establishment of NORDEFCO in 2009. ${ }^{14}$

In 2009, it was the realization of increased interdependencies, strategic as well as economic, that spurred the writing of what has become known as 'the Stoltenberg Report.'15 Written by former Norwegian foreign minister Thorvald Stoltenberg, the report drew on investigations into the potential for enhanced Nordic cooperation in the domains of

13 Gebhard 2017.

14 Dahl 2014, 5; Westberg 2015, 104; Saxi 2011, 49.

15 Stoltenberg 2009. 
security and defence. It concluded that Nordic security cooperation had great potential in the following core areas: peace building, air surveillance, maritime surveillance and the Arctic, civil emergency preparedness, the foreign services, and the military. The report also called for a solidarity declaration; one was adopted in 2011, albeit far less ambitious than what the report had suggested. The Stoltenberg Report's stated expectations drew on and encouraged existing interaction and practical collaboration between the Nordic militaries as a means of achieving greater integration and spillover between different defence mechanisms.

However, it is well-known, if not always admitted, that many initiatives within Nordic security and defence cooperation in the last 20 years have proven challenging, to say the least. On the one hand, the willingness and ideational rhetoric in political and defence circles appear to favour enhanced cooperation. In the years immediately after it was issued, the Stoltenberg Report served as a key constitutive document for envisioning a Nordic joint security project. Nordic security and defence communities have exhibited an almost euphoric enthusiasm for Nordic defence cooperation, ranging from ideas of joint force production and integration, ${ }^{16}$ the development of joint capabilities and force integration, ${ }^{17}$ a solidarity declaration, ${ }^{18}$ to joint unmanned aerial systems ${ }^{19}$ and more recently a commitment to deepened cooperation in the fields of defence industry, cyber, intelligence and exercises. ${ }^{20}$ The level of rhetorical ambition for Nordic cooperation has been high indeed.

On the other hand, while some initiatives have been implemented with varying degrees of success, others have hardly been implemented at all, or have seen slow progress and a lack of continuity - some eventually being brought to a halt. As will be discussed below, at worst, the problems of cooperation on defence materiel landed bilateral relationships in significant crises, particularly as regards joint projects for acquisition and procurement. That has been the area involving the most problems and the greatest challenges. Cooperation in that domain has been left in flux, with potential ramifications for other cooperation areas - all in spite of the exclaimed enthusiasm for Nordic cooperation. As one Norwegian MP asked the Foreign Minister in February 2017: 'Where are we really with the Stoltenberg report today?'21 One answer seems to have been given by a Norwegian MoD official who remarked, 'we are only now starting to sober up after years of euphoria over Nordic defence cooperation.'22

\footnotetext{
16 Innset 2008.

17 Norwegian Ministry of Defence 2012.

18 Stortinget 2011.

19 Ege 2015.

20 Søreide et al. 2015.

21 Norwegian Parliament 2017.

22 Interview with Norwegian MoD official, September 2017.
} 


\section{Nordic Defence Bureaucracies: Incompatibility and Legal Hurdles}

Analysts of Nordic defence cooperation have tended to ignore the difficulty of defence planning and organization across national borders, as well as the corporatist nature of the national defence organizations and agencies involved in regional cooperation efforts, like defence industries. ${ }^{23}$ Outside-in perspectives often underestimate the power potential of vested domestic interests. Material, economic and industrial factors have significant influence on the scope and formation of regional cooperation. Like we have discussed so far, they may also represent negative forces, obstructing the desired cooperation.

In addition, a bureaucratically contingent issue for Nordic defence cooperation has been the absence of coordinated accounting and reporting systems, as well as the inconsistent practices in the budget breakdown of military spending. These inconsistencies complicate the cost-saving measures, planning, and the potential for integration at the level of defence materiel. ${ }^{24}$ Lehtonen and Isojärvi's 2015 comparison of the list of future acquisition plans in Norway, Denmark, Finland and Sweden indicates that six years of promoting and incentivizing Nordic cooperation on political level have had little impact on the processes for planning and coordinating defence materiel acquisitions and procurement. One source of problems is the inherent difficulty in ensuring that all governance entrepreneurs involved in any defence collaboration have their interests more or less temporally aligned. ${ }^{25}$ More importantly perhaps, it is a matter of aligning specifications in materiel - a move that national armed forces would be naturally disinclined to take. March and Olsen's account of institutional dynamics in international political organizations captures this phenomenon with the 'competency trap': the tendency of institutions to become firmly locked into a specific structure governed by familiar rules, institutional arrangements or practices. ${ }^{26}$ This in turn creates problems as to adaptation and change, as the perceived disadvantages of new practices tend to press aside the exploration of new technologies and practices. ${ }^{27}$ Logistics and standards-setting are typical examples of domains with a strong path dependency. ${ }^{28}$

Nordic cooperation arrangements tend to be layered on top of already established and path-dependent practices within the respective defence institutions. Despite the topdown instructions to enhance cooperation, elements of the existing institutional arrangements continue to persist, and to shape developments..$^{29}$ Moreover, governance entrepreneurs, while relating mainly to each other or to the political level, may also relate directly

23 Schmitter 2004.

24 Giegereich and Nicoll 2012.

25 Lehtonen and Isojärvi 2015, 13.

26 March and Olsen 1998.

27 Ibid., 964-965.

28 De Vore 2012, 452.

29 Ibid., 438. 
to the global level, thus circumventing the objectives articulated on the national or regional political level.

A case in point is the 2009 EU Defence Procurement Directive, which has been differently interpreted by the Nordic defence bureaucracies. While legal regulations might seem to be an issue area left mainly for lawyers to resolve, in the context of defence materiel there can be major impacts on politics and regional relations. For example, legal conflicts were at the core of the largely failed joint Swedish/Norwegian acquisition of military trucks. ${ }^{30}$ Initiated in parallel to the Archer agreement (led by Sweden), this project was led by Norway and implemented in compliance with Norwegian regulations. However, complications arose when the Swedish Competition Authority launched an investigation into the appropriateness of the Norwegian interpretation as regards regulating Swedish procurements. This caused so much delay in the purchasing process that the FLO eventually decided to proceed with the project unilaterally. Issues also arose when the Swedish manufacturer Scania threatened to sue the FLO, based on accusations of a disorderly tendering process skewed in favour of the awarded German company, Rheinmetall MAS. ${ }^{31}$

Given the universal bureaucratic impulse to pursue enhanced wealth and autonomy, the staffs of highly resourceful organizations can induce politicians to adopt policies that are more in the interest of the organization's administration than in line with the political objectives. ${ }^{32}$ Moreover, joint ventures like these are experimental in nature, so it is not easy for organizations to justify continuation unless that makes sense in terms of immediate local returns. ${ }^{33}$ Episodes like the joint truck procurement seem to have had important learning effects in the ranks of defence administration representatives in Sweden and Norway, even resulting in shifts in conceptions of 'the national interest' - which may have been more important than the regional interest. For example, hedging against the risk of legal entanglement with neighbours by ensuring that procedures retain significant national autonomy has become an important priority among Nordic officials involved in cooperation on defence materiel. ${ }^{34}$

30 Bentzrød 2013a

31 Bentzrød 2013b.

32 De Vore 2012, 436.

33 March and Olsen 1998, 965.

34. Interviews with MoD staff in Denmark, Sweden and Norway, January-March 2018. 


\section{Nordic Defence Industries: Competition and Conflict}

The differences in ownership structure of the Nordic defence industries has represented an additional impediment to greater regional cooperation. ${ }^{35}$ In sharp contrast to the Swedish private ownership structure, in Norway the government has retained a significant share in the ownership of major arms companies (in comparison Finland has traditionally supported foreign ownership of its defence companies, whereas Denmark's limited and privately-owned defence industrial base makes its role insignificant in intra-Nordic defence trade). Sweden's defence industry is also significantly larger than Norway's: the Swedish defence industry employed in 2013 about 20,000 people, whereas the Norwegian defence industry employed in 2015 about 5000 people. $^{36}$

Such differences in company structures may influence how those involved feel about industrial cooperation efforts. The influence of ownership structure on company strategies could prove particularly relevant regarding best practices, or in questions of industrial offset strategies. For example, for Sweden, the Nordic region has traditionally been among the most important for defence exports. Hence, there would be few incentives for Swedish defence industries to harmonize or discard traditional elements of their technological base and their leading role- just as individual companies are unwilling to lose their competitive edge. ${ }^{37} \mathrm{~A}$ general ambition of Sweden's offset policy has therefore been to promote defence industrial activities in Sweden, and its superiority among the Nordic countries in general. ${ }^{38}$ More recently, Sweden has expanded its export strategy to encompass a Europe-first approach, next to a strong Asian outlook, focussing on 'whole solution' products and platforms. Norwegian exports are more niche and targeting mostly the transatlantic and American markets.

Competition is also prevalent between the Norwegian and Swedish industries, which generally have overlapping and competing competencies and products. The reverse is true as regards Norwegian and Finnish industries, which combined cover a complete 'lifecycle': while Norwegian industry leads in product development, Finnish industry offers some of the best in maintenance. In 2016 Norway's Kongsberg Defence \& Aerospace acquired 49.9\% of Finland's state-owned Patria, creating a major Nordic industrial defence group second in revenues only to Sweden's SAAB group. ${ }^{39}$ Defence industrial mergers like this are no doubt surrounded by an atmosphere charged with politics and security concerns. This acquisition is certain to have significant economic and political implications - possibly also for the relationship between Norway and Sweden in the domain of defence cooperation.

35 Breitenbauch et al. 2017.

36 Olsson and Nordlund 2017.

37 Hagelin 2009, 174.

38 Ibid.

39 Defence News 2016. 
Perhaps one of the least understood aspects of Swedish security policy has been the massive importance put on sales of fighter jets and submarines as a main security interest. Thus, when Norway announced in April 2016 that a French and a German company would be the final two candidates for its planned procurement of new submarines - meaning that the Swedish company SAAB Kockums had been ruled out in the initial round - created new tensions on the political level. Sweden deemed it particularly regrettable that the Norwegian press release cited the need for 'an existing submarine design', 'extensive experience' and the wish to 'avoid large developments with the risk, uncertainty and cost such a project entails' - all seen as reflecting negatively on Swedish submarine production. ${ }^{40}$

Studies of strategic culture have shown that strategic beliefs can be so deeply embedded in general and political culture that they tend to change slowly, constraining the effects of changes in a state's security environment on its security policy. ${ }^{41}$ This applies also to organizations, where identities and early organizational choices continue to shape the development of cooperation in a policy area long after the environment or policy-maker preferences may have changed. ${ }^{42}$ Nonetheless, the industries themselves appear slowly to become more determined to work together. A Joint Nordic Defence Industry Cooperation Group, aimed at strengthening ties and boosting cooperation, was launched by the Nordic defence industry associations in 2012. Additionally, differences in 'best practices' in Nordic defence industry associations have spurred NORDEFCO to develop an 'industry dialogue' between the respective Nordic associations. ${ }^{43}$ Paradoxically, however, the success of initiatives like these hinges on willingness to engage in experimentation that is unlikely to succeed and particularly unlikely to be immediately rewarding. ${ }^{44}$ Recent Swedish-Norwegian cooperation in defence materiel seems to have been subject to too much experimentation, leading to immediate disaster and a retreat to national pathways.

\section{The Failed Archer Artillery Project}

In December 2010, a highly prestigious defence materiel cooperation project was initiated between Norway and Sweden. After years of initial collaboration on R\&D, BAE Systems Bofors, ${ }^{45}$ was awarded a joint production contract to build 24 Archer artillery guns for each country. However, the project ended abruptly in December 2013, when Norway announced its withdrawal, citing delivery delays and performance shortcomings with regard

40 Norwegian Ministry of Defence 2016.

41 Neumann and Heikka 2005.

42 De Vore 2012, 451.

43 Brattberg 2017.

44 March and Olsen 1998, 965.

45 BAE SystemsBofors is the Swedish branch of the global defence industry giant BAE: https:// www.baesystems.com/en/our-companies/our-businesses/platforms-and-services/locations/ sweden 
to the terms of the contract. Norway's decision threw the collaboration into disarray, leaving Sweden with all 48 Archers. ${ }^{46}$

The political will for cooperation in the field of defence materiel and force integration underpinning the deal had been substantial. This was expressed by, inter alia, Norwegian Defence Minister Espen Barth Eide, who in 2012 declared that the Archer project was spearheading Nordic defence cooperation. ${ }^{47}$ Only days before Norway announced its withdrawal from the project, the Nordic defence ministers met in Helsinki, where Norwegian Defence Minister Ine Eriksen Søreide emphasized the importance of practical defence cooperation. ${ }^{48}$ Months earlier, the Nordic defence ministers had issued a joint statement praising Nordic defence cooperation as a great success. ${ }^{49}$

The aim of the Archer acquisition had been to secure cost efficiency, in addition to greater synergies in terms of operational effect and system resolution. One expectation would be that integration in one issue area - technical, between defence materiel administrations or through cooperative ventures - would create 'pressures for integrating contiguous areas for which the original area is crucial. ${ }^{50}$ However, numerous problems were encountered. Dissimilar organizational structures within Norway's defence materiel administration Forsvarets Logistikkorganisasjon (FLO) and the Swedish equivalent, Försvarets Materielverk (FMV), caused problems with regard to cooperation on leadership and decision-making. Suspicion and miscommunication, combined with differing views on quality control and management obstructed the cooperation process, ultimately leading to the lack of confidence. ${ }^{51}$

While some $\mathrm{e}^{52}$ assume that the process for resolving conflicts between member states during a cooperation process would make it simple to achieve a compromise, that was clearly difficult in the Archer case. The decision to cancel the project in its joint format was made upon recommendation from the Norwegian FLO, with clearly negative spill-over between the governance entrepreneurs and the political level. The political explosive force of failed cooperation on defence materiel can be significant. Among other things, it may lead to re-nationalization of attitudes and preferences - 'politicization', meaning the likelihood of controversiality and difficulty in reaching agreements..$^{53}$

\footnotetext{
46 de Larrinaga 2016.

47 Quoted in Saxi 2016, 74.

48 Norwegian Ministry of Defence 2013b.

49 Norwegian Ministry of Defence 2013a.

50 Andreatta 2011, 25.

51 Undén 2014, 31.

52 e.g. Schmitter and Lefkofridi 2016.

53 Schmitter 2005, 261.
} 
Another problem concerned perceptions and interpretations of what the project objectives really were, by the governance entrepreneurs involved - the many military officials, bureaucrats and practitioners interacting regionally, far below the political or global level of influence. Perceptions and interpretations varied radically indeed, especially on the level of project management: The Swedes were mostly concerned with the strategic business objective, namely that of a joint venture. In Norway, the project managers appeared more concerned with national military specifications and ensuring a national industrial balance; part of the arrangement had been that Sweden would purchase the Norwegian Remote Weapon Station (RWS) 'Protector'. Norway's choice of buying Swedish artillery was based mainly on the need for critical capabilities, and Sweden ended up as the supplier because the prerequisites for an offset project simply appeared to be met - in other words, a technical rationale. ${ }^{54}$ However, the Norwegian impression was that Sweden was motivated to collaborate on materiel because this would provide an opportunity to buttress Swedish strategic interests, as evident in the rather blatant expectations that the other Nordics would and should buy from Swedish industry. It became increasingly clear that the intent and motivational factors behind each governance entrepreneur's involvement were out of sync. In the end, the institutional self-interest and different interpretations of the project objectives led to disintegration.

\section{The Structural Effects of Archer}

As noted by Ojanen, ${ }^{55}$ successful European security and defence integration depends on the realization of mutual gains from cooperation in policy arenas characterized by high levels of functional interdependence - like defence. Moreover, it is presumed that technical experts (including bureaucrats) are anxious to expand their role in policy making, while seeking to avoid conflict.

Applying a power-resource view of the workings of international cooperation formats, Moravcsik has advanced the idea of 'informal supranational entrepreneurship' - that international officials exploit 'asymmetrical control over scarce information or ideas to influence the outcomes of multilateral negotiations, whether through persuasion, mediation or mobilization, ${ }^{56}$ By possessing information or ideational resources believed unavailable to the principals in a negotiation - national governments - supranational actors could exercise significant impact on the bargaining outcomes. However, as Moravcsik also notes, there is a widespread assumption that supranational entrepreneurs are better at representing the 'general interest': that they somehow act with greater impartiality than national governments, and therefore represent a kind of 'honest broker' in regional cooperation.

54 Undén 2014, 28-30.

55 Ojanen 2006.

56 Moravcsik 1999, 272. 
However, if we apply this theory on regional cooperation, and depict the governance entrepreneurs as the international defence industry, the picture is somewhat different. The Archer case would indicate that, despite the realization of mutual gains on the political level (which was underpinned by strong economic needs), on the practical level the entrepreneurs failed to act like 'honest brokers'. One example of interest driven conflict occurred when BAE Systems International initiated replacements in the Swedish BAE Bofors staff, causing delays and disturbances to the project management dynamics, as well as significantly altering the internal business culture. BAE's approach was seen as being mainly interest- driven on behalf of the global holding company and not of the Swedish subsidiary Bofors, thereby undermining the central leadership's ownership to the development process. ${ }^{57}$

Adding to the above issues is also that Norway and Sweden pursue slightly dissimilar acquisition strategies, as has been demonstrated in a recent report by the Swedish Defence Research Agency. ${ }^{58}$ While Norway and Sweden do share similar principles about acquisitions through fair competition between existing systems (in order to increase cost efficiency and short delivery timeframes) and international cooperation (in order to ensure interoperability and economies of scale), small but significant disparities significantly limit the scope for joint ventures. For example, the recognition in 2014 of Swedish submarine and air force technology as key security interests for the country has led to an exceptional shift away from the above principles. In 2014, only about 3,5\% of their acquisition funds were spent on purchasing the Swedish fighter jets JAS 39E and A26 submarines. However, over the coming years modifying and developing these two key security interests are expected to make up a significant part of Sweden's future defence investments. For other acquisitions, the demand for cost efficiency encourages the purchasing of products that are already available on the market.

In Norway too, the development of new systems by national industry is only considered economically justifiable if already existing products - so-called 'shelf products' - are not deemed to be more cost efficient or technically feasible (and for Norway, the best shelf products are usually found in the NATO-shop). In case of a need for developing and acquiring defence material domestically, importance is attached to developing systems unique to Norwegian conditions (including C2 systems, robotics, autonomous systems, subsea sensors and ammunition) that can also give Norwegian defence industry a competitive edge on the global market. Consequently, Norwegian and Swedish national acquisition strategies are locked into patterns where the national want for cost efficiency (by buying existing systems) and national technical expertise are in conflict with the objective of bilateral cooperation on developing new, joint systems. Thus, even if governance entrepreneurs were somehow 'honest brokers' in favour of bilateral cooperation, the national policy structures are not incentivising this outcome.

57 Undén 2014, 30.

58 Olsson and Nordlund 2017. 
The Archer project has had serious implications for Swedish-Norwegian political relations: negative personal experiences from cooperation in defence materiel led to bilateral mistrust that remained for years. According to Swedish sources, in the aftermath of Archer it was widely felt in Swedish defence circles that Norway had lost a significant degree of trust and credibility. On the political level, sentiment in Sweden was that how Norway had chosen to back out of the Archer project was 'simply unacceptable' at such a late stage in a project cycle. ${ }^{59}$ Immediately after news of the Norwegian withdrawal broke, Swedish Defence Minister Karin Enström declared that the decision was regrettable, adding that 'it would have ramifications for Norwegian-Swedish cooperation'. ${ }^{60}$ Further, the experience led to the realization that Norwegians and Swedes have distinctly different ways of approaching and interpreting the meaning of 'bilateral cooperation'.

True, bilateral meetings between Norwegian Defence Minister Ine Eriksen Søreide and her successor Frank Bakke-Jensen and Swedish Defence Minister Stefan Hultqvist over the last few years seem to have tackled the worst of the damage, but exactly how the relationship will now evolve remains unclear. Swedish-Norwegian bilateral defence cooperation is still fragile: it is beginning to recover after some heavy blows, but cannot be expected to sustain any major new setbacks. ${ }^{61}$ Occurrences like the case Archer give rise to questions of the capacity of the Nordic countries to deliver large-scale, added-value projects and contracts that can promote regional cohesion in the defence sphere.

Another indicator of the continued distrust could be the more recent Norwegian insistence on formal treaty-enshrined guaranties from Sweden and Finland in the NORDEF$\mathrm{CO}$ context. The Norwegian MoD have insisted on such formal commitments in cooperation projects of operational nature. The Norwegians are reluctant or unwilling to depend upon resources or systems from the non-allied neighbours unless they are guaranteed they will be available also in situations of crisis and conflict. ${ }^{62}$ Interestingly, fellow NATOmember Denmark, has apparently taken a more pragmatic and less legalistic approach to these issues. ${ }^{63}$

In general, politicians have been very supportive and positive to cooperation on joint acquisitions and procurement because this is seen as an important way to build strategic relations with partners. Beyond doubt, defence materiel is a highly politicized issue with ramifications far beyond the narrower realm of hardware and technology. Moreover, the problems are usually not caused by political quarrels; once a project has been politically agreed, responsibility for implementing and navigating it is largely left to experts and other implementing, or technical-operational, entrepreneurs. In fact, politicians tend to be wary of getting involved once a project is underway, implying that they trust in the

59 Friis and Bredesen 2017.

60 Eriksson 2013.

61 Friis and Bredesen 2017.

62 Saxi and Friis 2018.

63 Interviews with MoD staff in Denmark, Sweden and Norway, January-March 2018. 
governance entrepreneurs' ability to negotiate and agree without political guidance. In the Archer case, it was clearly the opposite: it was the poor cooperation between the governance entrepreneurs that eventually re-bounded back to the political level and required political action.

After the Archer project was terminated, few projects have been initiated bilaterally between Sweden and Norway. Although the possibility of similar projects has not been entirely dismissed, the methods and procedures have been changed, becoming more detached. Projects will no longer be managed by one administration (like FMV in the Archer case), but will have separate and nationally anchored management and contracting processes. ${ }^{64}$

This is not to say that there have not been any other successful Nordic acquisition and procurement projects. Completed or ongoing projects include joint procurement of lowhanging fruits such as CBRN protective masks, uniforms and ammunitions, for instance. However, there is little evidence that these have had an impact on regional force integration - not to mention the time, cost and other resources expended on the much larger unsuccessful undertakings. ${ }^{65}$ Taking these realities into account, the Norwegian armed forces concluded in 2015 that there would be no immediate gains within multilateral (regional) defence cooperation without sufficient political interest in solving the challenges. ${ }^{66}$ Subsequent efforts in the Norwegian Armed Forces have been directed at what may seem an unachievable target: a bigger defence budget - indicating a return to a more nationalized mindset about defence matters. ${ }^{67}$

National politicians, for their part, have had to realize that any benefits they might have envisioned from regional co-operation would eventually be overtaken by rising costs in terms of diminished sovereignty and practical entanglements, as well as industrial interests. Joint defence materiel projects have become extremely 'politicized', controversial and subject to disagreement, leading to what Schmitter calls the re-nationalization of attitudes and preferences. ${ }^{68}$ This has also led to the realization that cooperation on defence materiel is most feasible if it is limited to bilateral frameworks; more participants would increase the likelihood of problems exponentially. Thompson and Verdier call this variable the 'member surplus, ${ }^{69}$ relating to the compliance costs associated with multilateral cooperation: the more members, the more there will be potentially diverging interests.

64 Interview with Norwegian MoD official, September 2017.

65 Saxi 2016, 75; Hagelin 2006, 170.

66 Bruun-Hansen 2015.

67 Saxi 2016, 76.

68 Schmitter 2005, 261-263.

69 Thompson and Verdier 2014. 
A key Nordic priority now is to avoid any cooperation projects that might have similar negative spill-over effects. This may limit the extent to which cooperation can realistically go. The failure of materiel cooperation might also have ramifications for other types of military cooperation: even cooperating in the operative domain will to some extent depend on compatibilities and communalities in military equipment.

\section{The Future of Nordic Defence Cooperation}

While the Nordic states may represent an appealing image of level-headed, rational and common-sensical nations 'that know that politics is the art of the possible, ${ }^{70}$ recent developments in Norwegian-Swedish defence cooperation, chosen here as representing the wider Nordic context, indicate that 'common-senseness' is achieved only after years of trial and error. Practical security and defence cooperation between the two neighbours have proven far more challenging than what the keen political rhetoric might suggest.

This article has emphasized the interaction of governance entrepreneurs' interests and interpretations in shaping national preferences and choices for Nordic cooperation on defence materiel, highlighting how actors like defence industries and bureaucracies act with only incidental concern for the grand goal of regional cooperation. Through the example of Norwegian-Swedish cooperation, the article has demonstrated that outcomes for Nordic defence materiel cooperation cannot necessarily be predicted from the declarations in the Stoltenberg Report and other more recently expressed political ambitions. Cooperation between Norway and Sweden has been non-linear, conflict-ridden and the cause of negative (and potentially explosive) spillovers. The empirical evidence presented here shows that governance entrepreneurs may have a weakening and discordant effect on regional relationships - even leading to a weakening of government's political commitment to the Nordic cooperation project as articulated back in 2009.

Since Norway pulled out of Archer in 2013, the security landscape in Europe has changed. There are new and revitalized forces, both outside-in and inside-out and, pushing for new initiatives in Nordic defence cooperation, as discussed above. Nonetheless, NORDEFCO has primarily been focussing on exercise, training and other issues. There are no new ambitious proposals for Nordic joint procurement. ${ }^{71}$ In other words, the bottom-up spoiling forces remains stronger than the outside-in forces and even the inside-out forces in favour of increased cooperation - at least in terms of acquisition and procurement. This suggests that governments may set the terms of the initial agreement and (to some extent) what they can to control subsequent events - but that they alone do not determine how regional cooperative relationships develop.

70 Orvik 1974.

71 Saxi and Friis 2018. 
The recurrent cycles of endogenous contradictions and conflicts between the Norwegian and Swedish defence industries have also compelled the national authorities to revise their strategies. As a result, Norwegian-Swedish defence materiel cooperation has almost disappeared today, replaced by a return to more national concerns. The same appears to have happened on a regional level; there has been no coordinated development of the Nordic armed forces, and the intended system compatibility has not emerged. ${ }^{72}$ However, recent bilateral initiatives of Swedish-Finnish defence cooperation could over time also lead to closer interdependence, joint developments and ultimately force integration. But it is too early to conclude. Furthermore, in order to draw broader and more decisive conclusions about the regional level impact of national actors, more research is needed.

The inside-out and bottom-up perspective in this article has identified a dynamic of competition and conflict between Norway and Sweden - and one can assume, similar patterns exist elsewhere within the Nordic security region. The article has recognized that conflict can force governance entrepreneurs to seek only the lowest common denominator, thereby limiting the scope of regional cooperation. Experiences and lessons learned from past failures are involved in setting the premises for the likely evolution of regional cooperation. Politicians might set the framework and ambitions for cooperation, but ultimately it is the governance entrepreneurs in bureaucracy and industry who determine many of the conditions, perhaps even redefining the goals.

From a theoretical perspective and in a wider Nordic context, the article has also argued that emphasizing the outside-in structural push factors as a driver behind Nordic defence cooperation is a little off the mark. Admittedly, Nordic cooperation has acquired a much larger security dimension, due mainly to major developments and pressures in the European security environment since 2014. Revanchist Russian behaviour and assertiveness in the Baltic Sea, multiple challenges to the EU and the uncertainties of US policies have greatly increased the importance of regional cooperation in security and defence. However, a more scrutinising approach will show that the regional dynamics seen in the Nordic security region today are created not only outside-in or inside-out, but is also shaped by governance entrepreneurs, whose goals and aspirations operate in relative autonomy from the global and national political level.

Today, Nordic security cooperation is moving away from the euphoric idea of closer integration through cooperation on defence materiel, procurement and acquisition. It is increasingly acknowledged that, at the end of the day, grand ideas must give way to sober assessments, not least amongst policy-makers, and to pragmatism among practitioners.

72 Saxi 2016, 82. 


\section{References}

Adelman, Kenneth L., and Norman R. Augustine. 1990. The Defense Revolution: Strategy for the Brave New World. San Francisco: Institute for Contemporary Studies Press

Adler, Emanuel, and Michael Barnett, eds. 1998. "A framework for the study of security communities." Cambridge Studies in International Relations 62 (1): 29-66.

Adler-Nissen, Rebecca, and Ulrik Gad. 2014."Introduction: Postimperial sovereignty games in the Nordic region." Cooperation and Conflict 49 (1): 3-32.

Andonova, Liliana. 2017. Governance Entrepreneurs: International Organizations and the Rise of Global Public-Private Partnerships. Cambridge: Cambridge University Press.

Andreatta, Filippo. 2011. “The European Union's international relations: a theoretical view." In International relations and the European Union, edited by Christopher Hill and Michael Smith, 21-43. Oxford: Oxford University Press.

Bentzrød, Sveinung Berg. 2013a. "Forsvarssamarbeid mellom Norge og Sverige slår sprekker." Aftenposten 18 December. https://www.aftenposten.no/norge/i/0yVB/ Forsvarssamarbeid-mellom-Norge-og-Sverige-slar-sprekker

Bentzrød, Sveinung Berg. 2013b. "Tysk gigant fyrer løs mot Forsvarets lastebilkjøp." Aftenposten 19 December. https://www.aftenposten.no/norge/i/Eory5/Tysk-gigantfyrer-los-mot-Forsvarets-lastebilkjop

Brattberg, Erik. 2017. “Strengthening partnerships: Nordic defence collaboration amid regional security concerns." IHS Jane's Defence Weekly.

Breitenbauch, Henrik Østergaard. 2015. “Geopolitical Geworfenheit." Journal of Regional Security 10 (2): 113-133.

Breitenbauch, Henrik Østergaard et al. 2017. "Options for Enhancing Nordic Baltic Defence and Security Cooperation: An Explorative Study." University of Copenhagen: Centre for Military Studies.

Browning, Christopher, and Pertti Joenniemi. 2012. "From fratricide to security community: re-theorising difference in the constitution of Nordic peace." Journal of International Relations and Development 16 (4): 483-513.

Bruun-Hansen, Haakon. 2015. "Et Forsvar i endring. Forsvarssjefens fagmilitæreråd." Norway: Norwegian Armed Forces. 
Dahl, Ann-Sofie. 2014. "NORDEFCO and NATO: 'Smart Defence' in the North?" Rome: Research Division, NATO Defense College.

de Larrinaga, Nicholas. 2016. "Sweden to double Archer artillery purchase." IHS Jane's Defence Weekly, 21 September.

Deutsch, Karl Wolfgang. 1957. Political Community and the North Atlantic Area. Princeton, NJ: Princeton University Press.

De Vore, Marc. 2012. "Organizing international armaments cooperation: institutional design and path dependencies in Europe." European Security 21 (3): 432-458.

Defence News. 2016. "Kongsberg Buy-In at Patria Creates Nordic Industry Force." 17 March. https://www.defensenews.com/industry/2016/03/17/kongsberg-buy-in-atpatria-creates-nordic-industry-force/

Ege, Rune Thomas. 2015. "Vil Norge og Sverige skal samarbeide om droner og Afrika-operasjoner.” VG, 10 November. https:/www.vg.no/nyheter/utenriks/ i/49jro/sveriges-nye-forsvarssjef-i-eksklusivt-vg-intervju-vil-norge-og-sverige-skalsamarbeide-om-droner-og-afrika-operasjoner.

Eriksson, Mats. 2013. "Norge bryter svenskt vapenkontrakt." Sveriges Radio, 6 December. https://sverigesradio.se/sida/artikel.aspx? programid=83\&artikel $=5726468$

Friis, Karsten, and Maren Garberg Bredesen. 2017. "Swedish-Norwegian Defence Cooperation: New opportunities?” NUPI Policy Brief 7. Oslo: Norwegian Institute of International Affairs.

Forsberg, Tuomas. 2013. "The rise of Nordic defence cooperation: a return to regionalism?" International Affairs 89 (5): 1161-1181.

Gebhard, Carmen. 2017. "Scandinavian Defence and Alliance Policies: Different together." In Routledge Handbook on Scandinavian Politics, edited by Anders Wivel and Peter Nedergaard, 254-268. London: Routledge.

Giegerich, Bastian, and Alexander Nicoll. 2012. "The struggle for value in European defence." Survival 54 (1): 53-82.

Haas, Ernst Bernard. 1964. Beyond the Nation-State. Functionalism and International Organisations. Stanford: Stanford University Press.

Hagelin, Björn. 2006. "Hardware politics, 'hard politics' or 'where, politics?': Nordic defence equipment cooperation in the EU context." In The Nordic Countries and the 
European Security and Defence Policy, edited by Alyson J.K. Bailes, Gunilla Herolf and Bengt Sundelius, 167-184. Oxford: Oxford University Press.

Harris, Gardiner. 2016. “Obama warms up to Nordic leaders.” New York Times, 13 May. https://www.nytimes.com/2016/05/14/world/europe/obama-warms-to-nordicheads-of-state.html

Innset, Bjørn. 2010. "Integrasjon med grenser eller grenseløs integrasjon? En analyse av nordisk forsvarssamarbeid.” Sikkerhetspolitisk Bibliotek 3-2010. Oslo: The Norwegian Atlantic Committee.

Lehtonen, Juha-Matti, and Henry Isojärvi. 2015. "Nordic Armaments Co-operation Savings Potential." Journal of Military Studies 6 (2): 1-28.

Lundqvist, Stefan, and Jerker Widen. 2016. "Swedish-Finnish naval cooperation in the Baltic Sea: motives, prospects and challenges." Defence Studies 16 (4): 346-373.

March, James G., and Johan P. Olsen. 1998. “The Institutional Dynamics of International Political Orders." International Organisation 52 (4): 943-969.

Markusen, Ann. 2003. "Fuzzy concepts, scanty evidence, policy distance: the case for rigour and policy relevance in critical regional studies." Regional Studies 37 (6-7): $701-717$.

Moravcsik, Andrew. 1999. "A New Statecraft? Supranational Entrepreneurs and International Cooperation." International Organisation 53 (2): 267-306.

NATO News. 2015. "Secretary General stresses value of Nordic Defence Cooperation in visit to Sweden.” 10 November. http://www.nato.int/cps/en/natohq/news_124506. htm

Neumann, Iver. 1993. “A Region-Building Approach to Northern Europe." Review of International Studies 20 (1): 53-74.

Neumann, Iver, and Henrikki Heikka. 2005. "Grand Strategy, Strategic Culture, Practice: The Social Roots of Nordic Defence." Cooperation and Conflict 40 (1): 5-23

NORDEFCO. 2018. "Nordic Defence Cooperation Vision 2025." Statement by the Nordic Defence Ministers. 13 November.

https://www.regjeringen.no/contentassets/5aa571d66a1b4a708ae5fdedf8db5b83/ nordefco-vision-2025.pdf. 
Norwegian Ministry of Defence. 2012. "Et forsvar for vår tid.” Proposisjon til Stortinget 73 S (2011-2012). March 23.

https://www.regjeringen.no/contentassets/e6b0d7ef3c26457ab6ef177cd75b5d32/no/ pdfs/prp201120120073000dddpdfs.pdf

Norwegian Ministry of Defence. 2013a. "Nordisk forsvarssamarbeid gir gode resultater." News, 15 March. https://www.regjeringen.no/no/aktuelt/nordisk-forsvarssamarbeidgir-gode-resul/id717886/

Norwegian Ministry of Defence. 2013b. "Signertesamarbeidsavtale om transportfly." News, 4 December. https://www.regjeringen.no/no/aktuelt/signertesamarbeidsavtale-om-transportfl/id747330/

Norwegian Ministry of Defence. 2016. “Strategic partners for Norway's future submarines.” Press Release, 7 April. https://www.regjeringen.no/en/aktuelt/strategicpartners-for-norways-future-submarines/id2482241/

Norwegian Parliament. 2017. "Svar på spørsmål om status for rapporten om nordisk samarbeid om utenriks - og sikkerhetspolitikk". Question time, 1 March. Norway: Ministry of Foreign Affairs. https://www.regjeringen.no/no/aktuelt/nordisksikkerhet/id2540816/

Ojanen, Hanna. 2006. "The EU and NATO: two competing models for a common defence policy." JCMS: Journal of Common Market Studies 44 (1): 57-76.

Olsson, Per, and Peter Nordlund. 2017. "Effektiv materielförsörjning - Nordiska länders strategi, organisation och försvarsindustri." Report. Swedish Defence Research Agency. https://www.foi.se/rapportsammanfattning?reportNo=FOI-R--4452--SE

Orvik, Nils. 1974. "Nordic Cooperation and High Politics." International Organization 28 (1): $61-88$.

Pouliot, Vincent. 2010. International Security in Practice. The Politics of NATO-Russia Diplomacy. Cambridge: Cambridge University Press.

Saxi, Håkon Lunde. 2011. "Nordic Defence Cooperation after the Cold War." Oslo Files on Defence and Security, March. Oslo: Norwegian Institute of Defence Studies.

Saxi, Håkon Lunde. 2016. "Hvordan revitalisere NORDEFCO? En statusrapport og noen konkrete tiltak for å styrke samarbeidet i hverdagen." In Nordisk Forsvarssamarbejde 2016: Vilkår og muligheder, edited by Mikkel Storm Jensen, 61-92. Copenhagen: Forsvarsakademiet. 
Saxi, Håkon Lunde, and Karsten Friis. 2018. "After Crimea: The future of Nordic Defence Cooperation." NUPI Policy Brief, no. 6. Oslo: NUPI/IFS.

Schmitter, Philippe C. 2004. "Neo-Neofunctionalism.” In European Integration Theory, edited by Antje Wiener and Thomas Diez, 45-75. Oxford: Oxford University Press.

Schmitter, Philippe C. 2005. "Ernst B. Haas and the legacy of neofunctionalism." Journal of European Public Policy 12 (2): 255-272.

Schmitter, Philippe C., and Zoe Lefkofridi. 2016. "Neo-Functionalism as a Theory of Disintegration." Chinese Political Science Review 1: 1-29.

Stoltenberg, Thorvald. 2009. "Nordisk samarbeid om utenriks- og sikkerhetspolitikk." Report.

Norway: Norwegian Ministry of Foreign Affairs. February.

Stortinget.no. 2011. "Gledelig nordisk solidaritetserklæring." Stortinget Press Archive. 6 April. https://stortinget.no/no/Hva-skjer-pa-Stortinget/Nyhetsarkiv/Hva-skjernyheter/2010-2011/Gledelig-nordisk-solidaritetserklaring/

Søreide, Ine Eriksen et al. 2015. "Taking steps towards enhancing the cooperation on defence." Editorial/statement, 17 April. Oslo: Norwegian Ministry of Defence. https:// www.regjeringen.no/en/aktuelt/vi-utdyper-det-nordiske-forsvarssamarbeidet/ id2404378/.

Thompson, Alexander, and Daniel Verdier. 2014. "Multilateralism, Bilateralism, and Regime Design." International Studies Quarterly 58 (1): 15-28.

Undén, Pernille. 2014. "Nordiskt Försvarsmaterielsamarbete från ett aktörperspektiv." Master's thesis. Stockholm: Swedish National Defence College.

http://fhs.diva-portal.org/smash/record.jsf?pid=diva2\%3A730540\&dswid=5734

Westberg, Jacob. 2015. "Der nordiska försvarssamarbetets drivkrafter og utvecklingsmåojligheter." In Svänsk säkerhetspolitiki Europa och världen, edited by Kjell Engelbrekt, Arita Holberg and Jan Ångström, 89-116. Stockholm: Norstedtsjuridik.

Wæver, Ole. 1998. "Insecurity, Security and Asecurity in the West-European Non-War Community." In Security Communities, edited by Emanuel Adler and Michael Barnett, 69-118. Cambridge: Cambridge University Press. 